\title{
Influence of dietary fibre level on digestive and metabolic utilisation of energy in growing and finishing pigs
}

\author{
Gwénola Le Goff, Serge Dubois, Jaap van Milgen, Jean Noblet*
}

Institut National de la Recherche Agronomique, Unité Mixte de Recherches sur le Veau et le Porc, 35590 St-Gilles, France

(Received 6 September 2001; accepted 3 June 2002)

\begin{abstract}
The aim of the experiment was to determine the effect of dietary fibre (DF) level on the digestive and metabolic utilisation of energy in pigs. Two diets were prepared: a control low DF diet (the C diet, $100 \mathrm{~g}$ Total Dietary Fibre (TDF) $\left.\mathrm{kg}^{-1} \mathrm{DM}\right)$ and a fibre-rich diet $\left(200 \mathrm{~g} \mathrm{TDF} \cdot \mathrm{kg}^{-1} \mathrm{DM}\right)$ which corresponded to a combination of the $\mathrm{C}$ diet and maize bran (the MB diet). Each diet was fed as pellets during two successive experimental periods to five, individually caged pigs at growing (42 kg $\mathrm{BW})$ and finishing stages ( $76 \mathrm{~kg} \mathrm{BW})$ for the measurement of digestibility, heat production (HP; indirect calorimetry) and its components. Energy supply was standardised between the diets (2.4 and $2.3 \mathrm{MJ} \mathrm{ME} \cdot \mathrm{d}^{-1} \cdot(\mathrm{kg} \mathrm{BW})^{-0.60}$ for growing and finishing pigs, respectively). The energy digestibility was not affected by growth stage but was lower for the MB $\operatorname{diet}(83 \%)$ than for the C $\operatorname{diet}(91 \%)$. Similarly, the DE value of maize bran $\left(11.5 \mathrm{MJ}^{\mathrm{kg}} \mathrm{kg}^{-1} \mathrm{DM}\right)$, as calculated by the difference method, was similar at both stages. The fasting HP represented $56 \%$ of HP and averaged $0.724 \mathrm{MJ} \cdot \mathrm{d}^{-1} \cdot(\mathrm{kg} \mathrm{BW})^{-0.60}$ while the physical activity and thermic effect of feed represented on average 14 and $30 \%$ of HP, respectively. None of the components of HP was affected by the DF level. The activity HP was greater in finishing (16\% of HP) than in growing pigs $(12 \%)$. Energy cost of standing was constant $\left(\mathrm{kJ} \cdot \mathrm{min}^{-1}\right)$ when expressed per $\mathrm{kg} \mathrm{BW}^{1.25}$. When adjusted for similar ME intake and activity level, total HP and retained energy did not differ between the diets and between the growth stages. In conclusion, the metabolic utilisation of dietary energy was little affected by the DF level in growing and finishing pigs under the conditions of the present study.
\end{abstract}

pig / digestibility / energy value / dietary fibre / heat production

Résumé - Effet des parois végétales sur l'utilisation digestive et métabolique de l'énergie chez le porc en croissance et en finition. L'expérience a été mise en place afin de déterminer l'effet du taux de parois végétales sur l'utilisation digestive et métabolique de l'énergie chez le porc. Deux aliments ont été préparés : un régime témoin (régime T) à faible teneur en fibres totales $\left(100 \mathrm{~g} \cdot \mathrm{kg}^{-1} \mathrm{MS}\right)$

\footnotetext{
* Correspondence and reprints

Tel.: 33 (0)2 2348 50 49; fax: 33 (0)2 234850 80; e-mail: noblet@st-gilles.rennes.inra.fr
} 
et un régime enrichi en parois végétales ( $200 \mathrm{~g}$ de fibres totales par $\mathrm{kg} \mathrm{MS}$ ) où une fraction du régime T est remplacée par des drèches de maïs (régime DM). Chaque régime a été distribué successivement à 5 porcs au stade croissance ( $42 \mathrm{~kg} \mathrm{PV}$ ) et au stade finition $(76 \mathrm{~kg}$ ). Les animaux étaient maintenus individuellement en cage métabolique placée dans une chambre respiratoire afin de mesurer les coefficients d'utilisation digestive de l'énergie et des nutriments ainsi que la production de chaleur totale (calorimétrie indirecte) et ses composantes. Les niveaux alimentaires ont été égalisés à chaque stade $\left(2,4\right.$ et $2,3 \mathrm{MJ} \mathrm{EM} \cdot \mathrm{j}^{-1} \cdot \mathrm{kg} \mathrm{PV}^{-0,60}$ pour les porcs en croissance et en finition, respectivement). Le coefficient d'utilisation digestive de l'énergie n'était pas différent selon le stade de croissance des animaux ; à chaque stade il était plus faible pour le régime $\mathrm{DM}(83 \%)$ que pour le régime $\mathrm{T}(91 \%)$. De la même façon, la valeur ED des drèches de maïs $\left(11,5 \mathrm{MJ} \cdot \mathrm{kg}^{-1} \mathrm{MS}\right)$, déterminée à l'aide du calcul par différence, était comparable aux deux stades. La production de chaleur à jeun $\left(0,724 \mathrm{MJ} \cdot \mathrm{j}^{-1} \cdot \mathrm{kg}\right.$ $\mathrm{PV}^{-0,60}$ ) représentait en moyenne $56 \%$ de la production de chaleur totale tandis que la production de chaleur liée à l'activité physique et l'effet thermique de l'aliment en représentaient 14 et $30 \%$, respectivement. Les composantes de la production de chaleur n'ont pas été affectées par la teneur en parois végétales de l'aliment. La production de chaleur liée à l'activité physique était plus importante chez le porc en finition ( $16 \%$ de la production de chaleur totale) que chez le porc en croissance $(12 \%)$. Le coût énergétique de la station debout $\left(\mathrm{kJ} \cdot \mathrm{min}^{-1}\right)$ est constant lorsqu'il est exprimé par $\mathrm{kg}$ $\mathrm{PV}^{1,25}$. Après ajustement de l'EM ingérée et du niveau d'activité physique pour l'ensemble de l'expérience, la production de chaleur totale ainsi que l'énergie retenue s'avèrent similaires quels que soient l'aliment et le stade physiologique. En conclusion, l'utilisation métabolique de l'énergie de l'aliment a été peu influencée par le taux de parois végétales chez le porc en croissance ou en finition dans les conditions de notre étude.

\section{porc / digestibilité / valeur énergétique / parois végétales / production de chaleur}

\section{INTRODUCTION}

The cost of feed represents a large proportion of the total cost of pig production. Therefore, there is an economic interest in feeding diets that are high in relatively inexpensive ingredients such as cereal by-products. In addition, the increased availability of fibre-rich ingredients such as maize bran from starch extraction favours the increased utilisation in pig feeds. In maize bran, the dietary fibre (DF) fraction represents about $50 \%$ of organic matter. Accordingly, it is important to determine the effects of this fraction on both the digestive and metabolic utilisation of energy in pigs. First, it has been clearly demonstrated that an increased DF level decreases the digestibility coefficients of energy and nutrients in growing pigs. This effect becomes less pronounced with increasing body weight (BW) of pigs [5, 21]. The metabolic utilisation of energy is also expected to be af- fected since the net energy equations proposed by Noblet et al. [17] and the biochemical approach of Dierick et al. [7] indicate a greater heat increment of DF than of the other fractions. However, these results were not always confirmed by measurements of heat production (HP) in which fibre-rich diets were fed to growing pigs $[11,28]$. These contrasting results question the real effect of DF on energy utilisation and the rate of energy utilisation of the DF fraction in growing pigs. In addition, it is possible that feeding fibre-rich diets does not affect total HP, but it may affect the components of HP (e.g., due to changes in physical activity). The aim of the present experiment was to determine the effect of DF level on the digestive and metabolic utilisation of energy and components of HP in pigs at growing $(40 \mathrm{~kg})$ and finishing stages $(80 \mathrm{~kg})$; the variation of the DF level was induced by maize bran addition. 


\section{MATERIALS AND METHODS}

\subsection{Animals and diets}

Five blocks of two Piétrain $\times$ (Large White $\times$ Landrace) littermate barrows with an initial mean BW of $30 \mathrm{~kg}$ were used. All animals came from the herd of the Institut National de la Recherche Agronomique (Saint-Gilles, France). During the study, the pigs were individually housed in metabolism crates located in a temperature-controlled room $\left(23 \pm 1^{\circ} \mathrm{C}\right)$. Care and use of the animals were performed according to the Certificate of Authorisation to Experiment on Living Animals (certificate numbers 07704 and 04739 , provided by the French Ministry of Agriculture to van Milgen J. and Noblet J., respectively). During the experimental periods, the pigs were fed one of two diets differing in Total Dietary Fibre (TDF) contents (Tabs. I and II). The $\mathrm{C}$ diet was a control low dietary fibre $\operatorname{diet}\left(100 \mathrm{~g} \mathrm{TDF} \cdot \mathrm{kg}^{-1} \mathrm{DM}\right)$ and the MB diet corresponded to a combination of the $\mathrm{C}$ diet and maize bran (200 $\mathrm{g}$ TDF $\left.\cdot \mathrm{kg}^{-1} \mathrm{DM}\right)$; the diets were given as pellets (diameter $4.5 \mathrm{~mm}$; pelleting at $\sim 60^{\circ} \mathrm{C}$ ). During the non-experimental periods, the pigs received a standard diet (Tab. I).

\subsection{Experimental design}

Each barrow was used during two successive experimental periods (the growing (G) and finishing (F) periods) separated by a 5-week non-experimental period. Within each litter (i.e. block), one pig was allotted to the $\mathrm{C}$ diet and the other one to the $\mathrm{MB}$ diet. The pigs received the same diet during both experimental periods. During each period, the pigs were adapted to the diet for $10 \mathrm{~d}$ and subsequently moved to metabolism cages for collection of faeces and urine for nine days for digestibility measurements. During the last six days of the experimental period, each metabolism cage was placed in a respiration chamber where gas

Table I. Composition of the diets.

\begin{tabular}{lccc}
\hline & & \multicolumn{2}{c}{ Experimental diets } \\
\cline { 3 - 4 } Components $\left(\mathrm{g} \cdot \mathrm{kg}^{-1}\right.$ diet $)$ & Standard & $\mathrm{C}$ & $\mathrm{MB}$ \\
\hline Wheat & 243.9 & 899 & 680.9 \\
Isolated soybean proteins & - & 68.5 & 51.9 \\
Maize bran & - & - & 234.7 \\
Barley & 250.0 & - & - \\
Maize & 160.0 & - & - \\
Wheat bran & 50.0 & - & - \\
Soybean meal & 230.0 & - & - \\
Cane molasses & 30.0 & - & - \\
Lysine HCl & 0.6 & - & - \\
Dicalcium phosphate & 12.0 & 12.0 & 12.0 \\
Calcium carbonate & 14.0 & 11.0 & 11.0 \\
Salt & 4.5 & 4.5 & 4.5 \\
Vitamins and minerals mixture $^{1}$ & 5.0 & 5.0 & 5.0
\end{tabular}

$\mathrm{C}=$ control diet; $\mathrm{MB}=$ maize bran diet.

${ }^{1}$ The vitamins and minerals mixture provided the following (per kg diet): $2.7 \mathrm{mg}$ retinyl palmitate; $25 \mu \mathrm{g}$ cholecalciferol; $20.0 \mathrm{mg}$ dl- $\alpha$-tocopherol acetate; $2.0 \mathrm{mg}$ thiamin; $4.0 \mathrm{mg}$ riboflavin; $1.0 \mathrm{mg}$ pyridoxine; $20 \mu \mathrm{g}$ cobalamin; $15 \mathrm{mg}$ niacin; $9.9 \mathrm{mg}$ d-panthotenate; $200 \mu \mathrm{g}$ biotin; $1 \mathrm{mg}$ folic acid; $2.0 \mathrm{mg}$ menadione; $500 \mathrm{mg}$ choline chloride; $100.2 \mathrm{mg} \mathrm{Zn;} 10.0 \mathrm{mg} \mathrm{Cu} ; 37.0 \mathrm{mg} \mathrm{Mn} ; 80.0 \mathrm{mg} \mathrm{Fe} ; 202 \mu \mathrm{g} \mathrm{I} ; 100 \mu \mathrm{g} \mathrm{Co} ; 150 \mu \mathrm{g} \mathrm{Se}$. 
Table II. Chemical composition $\left(\mathrm{g} \cdot \mathrm{kg}^{-1} \mathrm{DM}\right)$ of maize bran and the experimental diets.

\begin{tabular}{lccc}
\hline & Maize bran & Diet C & Diet MB \\
\hline Ash & 28 & 49 & 51 \\
Crude protein $(\mathrm{N} \times 6.25)$ & 162 & 171 & 168 \\
Ether extract & 45 & 16 & 23 \\
Crude fibre & 110 & 27 & 46 \\
NDF & 495 & 107 & 197 \\
ADF & 126 & 28 & 51 \\
ADL & 18 & 8 & 10 \\
TDF & 482 & 103 & 197 \\
Starch & 243 & 596 & 516 \\
Sugars & 3 & 28 & 22 \\
Gross Energy $\left(\mathrm{MJ} \cdot \mathrm{kg}^{-1} \mathrm{DM}\right)$ & 19.59 & 17.97 & 18.19 \\
\hline
\end{tabular}

Diet $\mathrm{C}=$ control diet; Diet $\mathrm{MB}=$ maize bran diet $\mathrm{DM}=$ dry matter; $\mathrm{NDF}=$ neutral detergent fibre; $\mathrm{ADF}=$ acid detergent fibre; $\mathrm{ADL}=$ acid detergent lignin; $\mathrm{TDF}=$ total dietary fibre.

exchanges $\left(\mathrm{O}_{2}, \mathrm{CO}_{2}\right.$ and $\left.\mathrm{CH}_{4}\right)$ were measured. The pigs were kept in the respiration chambers for one additional day for estimation of the fasting heat production (FHP). During the experimental period, feed allowance was increased in order to provide 2.4 and $2.3 \mathrm{MJ} \cdot \mathrm{d}^{-1} \cdot(\mathrm{kg} \mathrm{BW})^{-0.60}$ during the $\mathrm{G}$ and the $\mathrm{F}$ periods, respectively. Feed was given to the animals in three approximately equal meals when they were not in the respiration chamber and in five equal meals (at $09.00,13.00,17.00,21.00$ and 01.00 hours using automatic feeders) while in the respiration chamber. Water was available ad libitum.

Two open-circuit respiration chambers based on a design described recently by Noblet et al. [18] were used simultaneously. The volume of each chamber was approximately $12 \mathrm{~m}^{3}$. The temperature was maintained at $24.0( \pm 0.1){ }^{\circ} \mathrm{C}$ and relative humidity was $70 \%$. Artificial light was used between 08.15 and 21.15 hours. Each chamber contained an individual metabolism cage equipped with two infrared beams to detect standing or sitting positions of the animal. Interruption of an infrared beam for at least $20 \mathrm{~s}$ was considered to be physical activity (i.e. standing or sitting) of the animal. In addition, the metabolism cage was placed on four force sensors, which produced an electric signal assumed proportional to the physical activity of the animal. The weight of the trough was measured continuously by a load cell and periods of instability were considered to correspond to meal consumption [18].

\subsection{Measurements}

The pigs were weighed at the beginning and at the end of each collection period. For each diet and each pig at each period, a sample of feed was collected and measured for its dry matter (DM) content; samples of each diet were subsequently pooled for chemical analyses. Faeces were collected daily, stored at $4{ }^{\circ} \mathrm{C}$ and weighed, homogenised and sub-sampled at the end of the period. One faeces sample was heat-dried for DM determination and a second one freezedried for further chemical analyses. Urine was collected daily, weighed and an aliquot was taken; aliquots of each animal were combined for chemical analyses at the end of the period. The $\mathrm{N}$ losses in the air, which were recovered in condensed water, and outgoing air from the respiration chamber 
were measured according to the method described by Noblet et al. [17].

During the seven day period in the respiration chamber, gas concentrations $\left(\mathrm{O}_{2}\right.$, $\mathrm{CO}_{2}$ and $\mathrm{CH}_{4}$ ) of outgoing air and ventilation rate were continuously measured as previously described [18]. Over the same time span, the signal of the force sensors was recorded. When the weight of the trough was detected as unstable, the corresponding beginning and ending times were recorded. Measurements of gas concentration, signals of the force sensors, instability of the trough and physical characteristics of the gas in the chamber (temperature, relative humidity, barometric pressure) were recorded 60 times per second, averaged over 10 second intervals and stored on a microcomputer for further calculations.

\subsection{Chemical analyses}

For feed samples, methods of the AOAC [1] were used for measuring DM, ash, CP $(\mathrm{N} \times 6.25)$, Weende crude fibre, and ether extract. Gross energy (GE) content was measured using an adiabatic bomb calorimeter (IKA C5000, Staufen, Germany). Cell wall fractions (NDF, ADF and ADL) were determined according to the methods of Van Soest and Wine [32] by using a sequential procedure with a previous amylolytic treatment. Total dietary fibre (TDF) was quantified according to the method of Prosky [23]. Starch content was measured using the Ewers polarimetric method [8], and sugars corresponded to alcohol-soluble carbohydrates obtained by the method of Luff-Schoorl [2]. The DM, ash, CP, NDF, $\mathrm{ADF}, \mathrm{TDF}$ and GE analyses were carried out on each sample of the faeces. In addition, the ether extract after hydrochloric acid hydrolysis was measured on pooled samples of faeces (one per diet and per physiological stage). $\mathrm{N}$ in the urine and in condensed water was measured on fresh material. Energy content in the urine was obtained after freeze-drying of approximately $30 \mathrm{~mL}$ in polyethylene bags.

\subsection{Calculations and statistical analyses}

Apparent digestibility coefficients of organic matter, nutrients and energy of diets and their DE and ME contents were calculated using routine procedures [21]. Total tract digestibility coefficients of energy and nutrients and energy values of maize bran were determined using the difference method [21]. $\mathrm{N}$ retention was obtained as the difference between $\mathrm{N}$ intake and $\mathrm{N}$ losses in the faeces, urine, condensed water, and outgoing air. The respiratory quotient was calculated as the ratio between $\mathrm{CO}_{2}$ production and $\mathrm{O}_{2}$ consumption. Daily heat production (HP) was calculated from gas exchanges (indirect calorimetry) according to the Brouwer equation [4], including methane production and urinary $\mathrm{N}$. The first day in the respiration chamber was considered as a day of adaptation and was not considered in the calculations. The retained energy (RE) corresponded to the difference between ME intake and HP. Energy retained as protein was calculated from $\mathrm{N}$

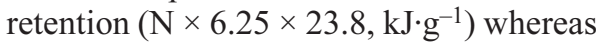
energy retained as lipids corresponded to the difference between RE and energy retained as protein.

The components of HP were estimated daily for each pig according to the model proposed by van Milgen et al. [31] and illustrated in recent papers $[25,30]$. In brief, on days when the animals were fed, HP was considered as the sum of resting heat production (RHP), short-term thermic effect of feed $\left(\mathrm{TEF}_{\mathrm{st}}\right)$ and $\mathrm{HP}$ due to physical activity $\left(\mathrm{HP}_{\mathrm{act}}\right)$. The so-called "ghost" effect characterised by a nocturnal increase in HP not related to feed or physical activity was also calculated and included in the $\mathrm{TEF}_{\mathrm{st}}[30]$; the "ghost" effect represented on average $1.9 \%$ (range: 0.6 to $4.9 \%$ ) of HP. Calculation on the fasting day provided an estimate 
Table III. Comparative digestive use of diets and nitrogen balance in growing and finishing pigs.

\begin{tabular}{|c|c|c|c|c|c|c|c|c|}
\hline \multirow[b]{2}{*}{ Diet } & \multicolumn{2}{|c|}{ Growing pig } & \multicolumn{2}{|c|}{ Finishing pig } & \multirow{2}{*}{ RSD } & \multicolumn{3}{|c|}{ Significance level $^{1}$} \\
\hline & $\mathrm{C}$ & MB & $\mathrm{C}$ & $\mathrm{MB}$ & & Diet & $\begin{array}{l}\text { Growth } \\
\text { stage }\end{array}$ & $\begin{array}{c}\text { Growth } \\
\text { stage } \times \text { diet }\end{array}$ \\
\hline No. of observations & 5 & 5 & 5 & 5 & & & & \\
\hline Body weight (kg) & $41.0^{\mathrm{b}}$ & $42.4^{\mathrm{b}}$ & $75.7^{\mathrm{a}}$ & $76.9^{\mathrm{a}}$ & 1.0 & NS & $* *$ & NS \\
\hline DM intake $\left(\mathrm{g} \cdot \mathrm{d}^{-1}\right)$ & 1386 & 1556 & 1940 & 2140 & NA & NA & NA & NA \\
\hline Average daily gain (g) & $706^{\mathrm{b}}$ & $715^{\mathrm{b}}$ & $915^{\mathrm{a}}$ & $953^{\mathrm{a}}$ & 112 & NS & $*$ & NS \\
\hline \multicolumn{9}{|c|}{ Digestibility coefficients (\%) } \\
\hline Dry matter & $90.5^{\mathrm{a}}$ & $82.6^{\mathrm{b}}$ & $90.4^{\mathrm{a}}$ & $83.0^{\mathrm{b}}$ & 0.7 & $* *$ & NS & NS \\
\hline Organic matter & $92.3^{\mathrm{a}}$ & $84.3^{\mathrm{b}}$ & $92.4^{\mathrm{a}}$ & $84.8^{\mathrm{b}}$ & 0.7 & $* *$ & NS & NS \\
\hline Crude protein & $91.5^{\mathrm{a}}$ & $85.7^{\mathrm{b}}$ & $92.6^{\mathrm{a}}$ & $87.0^{\mathrm{b}}$ & 0.9 & $* *$ & $*$ & NS \\
\hline Ether extract & 50 & 55 & 55 & 59 & NA & NA & NA & NA \\
\hline Crude fibre & 52.7 & 46.6 & 48.5 & 47.9 & 3.7 & NS & NS & NS \\
\hline NDF & $63.3^{\mathrm{a}}$ & $50.5^{\mathrm{b}}$ & $61.8^{\mathrm{a}}$ & $53.8^{\mathrm{b}}$ & 4.2 & $* *$ & NS & NS \\
\hline $\mathrm{ADF}$ & 39.7 & 41.6 & 41.3 & 44.9 & 4.1 & NS & NS & NS \\
\hline TDF & $54.9^{\mathrm{a}}$ & $45.3^{\mathrm{b}}$ & $55.9^{\mathrm{a}}$ & $49.2^{\mathrm{a}, \mathrm{b}}$ & 4.7 & $*$ & NS & NS \\
\hline Energy & $90.8^{\mathrm{a}}$ & $82.6^{\mathrm{b}}$ & $91.0^{\mathrm{a}}$ & $83.2^{\mathrm{b}}$ & 0.9 & $* *$ & NS & NS \\
\hline Digestible NDF $\left(\mathrm{g} \cdot \mathrm{d}^{-1}\right)^{2}$ & 94 & 154 & 128 & 227 & 11 & $* *$ & $* *$ & $*$ \\
\hline Energy as $\mathrm{CH}_{4}(\% \mathrm{DE})^{2}$ & 0.20 & 0.32 & 0.24 & 0.48 & 0.21 & NS & NS & NS \\
\hline Energy in urine (\% DE) & $3.0^{\mathrm{b}}$ & $3.3^{\mathrm{a}, \mathrm{b}}$ & $3.1^{\mathrm{b}}$ & $3.5^{\mathrm{a}}$ & 0.2 & $*$ & $\dagger$ & NS \\
\hline ME/DE (\%) & $96.8^{\mathrm{a}}$ & $96.4^{\mathrm{b}}$ & $96.7^{\mathrm{a}, \mathrm{b}}$ & $96.0^{c}$ & 0.2 & $*$ & $*$ & NS \\
\hline \multicolumn{9}{|l|}{ Nitrogen balance $\left(\mathrm{g} \cdot \mathrm{d}^{-1}\right)$} \\
\hline Nitrogen intake & $38.0^{\mathrm{d}}$ & $41.8^{\mathrm{c}}$ & $53.2^{\mathrm{b}}$ & $57.5^{\mathrm{a}}$ & 0.6 & $* *$ & $* *$ & NS \\
\hline \multicolumn{9}{|l|}{ Nitrogen losses } \\
\hline In faeces & $3.2^{\mathrm{c}}$ & $5.9^{\mathrm{b}}$ & $3.9^{\mathrm{c}}$ & $7.4^{\mathrm{a}}$ & 0.5 & $* *$ & $* *$ & NS \\
\hline In urine and gas & $17.4^{\mathrm{c}}$ & $18.1^{\mathrm{c}}$ & $25.0^{\mathrm{b}}$ & $26.0^{\mathrm{a}}$ & 0.5 & NS & $* *$ & NS \\
\hline Nitrogen retention & $17.4^{\mathrm{b}}$ & $17.8^{\mathrm{b}}$ & $24.3^{\mathrm{a}}$ & $24.0^{\mathrm{a}}$ & 0.5 & NS & $* *$ & NS \\
\hline
\end{tabular}

$\mathrm{C}=$ control diet $\mathrm{MB}=$ maize bran diet; $\mathrm{DM}=$ dry matter; $\mathrm{NDF}=$ neutral detergent fibre $; \mathrm{ADF}=$ acid detergent fibre; $\mathrm{TDF}=$ total dietary fibre; $\mathrm{CH}_{4}=$ methane production; $\mathrm{DE}=$ digestible energy; $\mathrm{RSD}=$ residual standard deviation.

${ }^{1}$ From analysis of variance where main effects were animal within diet and litter $(\mathrm{n}=10)$, litter $(\mathrm{n}=5)$, diet $(\mathrm{n}=2)$, growth stage $(\mathrm{n}=2)$ and the interaction between diet and growth stage; the effects of animal and litter were not significant $(P>0.10)$. The interactions between stage and litter and between diet and litter were also tested but were not significant. Levels of significance: $\uparrow, P<0.10$; $^{*}, P<0.05$; *,$P<0.01$; NS, not significant; NA, not applicable. The same animals were used at growing and finishing stages and received the same diet. Ether extract of faeces was measured on samples pooled per diet and per pig stage and corresponding digestibility coefficients could not be submitted to the analysis of variance.

${ }^{\mathrm{a}-\mathrm{c}}$ Mean values within a row with unlike superscript letters were significantly different, $P<0.05$.

${ }^{2}$ Methane energy losses $\left(\mathrm{kJ} \cdot \mathrm{d}^{-1}\right)$ were linearly related to digestible NDF content $\left(\mathrm{g} \cdot \mathrm{d}^{-1}\right): \mathrm{y}=-36+0.85 \mathrm{x}$ $\left(\mathrm{R}^{2}=0.42\right)$. The relationship was not affected by pig stage $(P<0.05)$ nor by animal within diet and litter $(P<0.05)$.

of fasting heat production (FHP) for zero physical activity. The difference between RHP and FHP was used to calculate the long-term thermic effect of feed $\left(\mathrm{TEF}_{\mathrm{lt}}\right)$.
Finally, four components of daily HP were obtained: FHP, TEF ${ }_{1}, \mathrm{TEF}_{\text {st }}$, and $\mathrm{HP}_{\mathrm{act}}[31]$. The total TEF corresponded to the sum of $\mathrm{TEF}_{\mathrm{st}}$ and $\mathrm{TEF}_{\mathrm{lt}}$. Components of HP were 
Table IV. Effect of diet composition on heat production and energy balance in growing and finishing pigs.

\begin{tabular}{|c|c|c|c|c|c|c|c|c|}
\hline \multirow[b]{2}{*}{ Diet } & \multicolumn{2}{|c|}{ Growing pig } & \multicolumn{2}{|c|}{ Finishing pig } & \multirow[b]{2}{*}{ RSD } & \multicolumn{3}{|c|}{ Significance level $^{1}$} \\
\hline & $\mathrm{C}$ & MB & $\mathrm{C}$ & MB & & Diet & $\begin{array}{l}\text { Growth } \\
\text { stage }\end{array}$ & $\begin{array}{c}\text { Growth } \\
\text { stage } \times \text { diet }\end{array}$ \\
\hline Body weight $(\mathrm{kg})^{2}$ & 42.1 & 43.6 & 77.9 & 78.5 & 1.1 & NS & $* *$ & NS \\
\hline \multicolumn{9}{|c|}{ Energy balance $\left(\mathrm{MJ} \cdot \mathrm{d}^{-1} \cdot \mathrm{kg}^{-0.60}\right)$} \\
\hline $\mathrm{DE}$ & $2.399^{\mathrm{a}, \mathrm{b}}$ & $2.429^{\mathrm{a}, \mathrm{b}}$ & $2.325^{\mathrm{b}}$ & $2.361^{\mathrm{a}, \mathrm{b}}$ & 0.043 & $\mathrm{NS}$ & $*$ & NS \\
\hline ME & $2.359^{\mathrm{a}, \mathrm{b}}$ & $2.379^{\mathrm{a}}$ & $2.255^{\mathrm{b}}$ & $2.301^{\mathrm{a}, \mathrm{b}}$ & 0.061 & NS & $*$ & NS \\
\hline \multicolumn{9}{|l|}{ Heat production (HP) } \\
\hline As FHP & $0.721^{\mathrm{a}, \mathrm{b}}$ & $0.743^{\mathrm{a}}$ & $0.711^{\mathrm{b}}$ & $0.723^{\mathrm{a}, \mathrm{b}}$ & 0.017 & NS & NS & NS \\
\hline As $\mathrm{HP}_{\mathrm{act}}$ & $0.150^{\mathrm{b}}$ & $0.144^{\mathrm{b}}$ & $0.212^{\mathrm{a}}$ & $0.203^{\mathrm{a}}$ & 0.020 & NS & $* *$ & NS \\
\hline As TEF & $0.396^{\mathrm{a}}$ & $0.391^{\mathrm{a}, \mathrm{b}}$ & $0.352^{\mathrm{b}}$ & $0.390^{\mathrm{a}, \mathrm{b}}$ & 0.022 & NS & $\dagger$ & NS \\
\hline Total HP & $1.267^{\mathrm{b}}$ & $1.278^{\mathrm{b}}$ & $1.276^{\mathrm{b}}$ & $1.316^{\mathrm{a}}$ & 0.021 & $*$ & $\dagger$ & NS \\
\hline \multicolumn{9}{|l|}{ Retained energy (RE) } \\
\hline As protein & $0.278^{\mathrm{a}}$ & $0.279^{\mathrm{a}}$ & $0.265^{b}$ & $0.264^{\mathrm{b}}$ & 0.009 & NS & $*$ & NS \\
\hline As lipid & $0.813^{\mathrm{a}}$ & $0.821^{\mathrm{a}}$ & $0.713^{b}$ & $0.720^{\mathrm{b}}$ & 0.061 & NS & $*$ & NS \\
\hline Total & $1.091^{\mathrm{a}, \mathrm{b}}$ & $1.100^{\mathrm{a}}$ & $0.979^{c}$ & $0.984^{\mathrm{b}, \mathrm{c}}$ & 0.063 & NS & $*$ & NS \\
\hline Respiratory quotient & $1.19^{\mathrm{a}}$ & $1.17^{\mathrm{a}, \mathrm{b}}$ & $1.16^{\mathrm{a}, \mathrm{b}}$ & $1.14^{\mathrm{b}}$ & 0.02 & $\mathrm{NS}$ & $*$ & NS \\
\hline Heat production (\% ME) & $53.7^{\mathrm{b}}$ & $53.7^{\mathrm{b}}$ & $56.6^{\mathrm{a}, \mathrm{b}}$ & $57.2^{\mathrm{a}}$ & 1.7 & NS & * & NS \\
\hline \multicolumn{9}{|l|}{ TEF (\% ME) } \\
\hline As short-term ${ }^{3}$ & $9.1^{\mathrm{a}, \mathrm{b}}$ & $9.2^{\mathrm{a}, \mathrm{b}}$ & $10.5^{\mathrm{a}}$ & $7.2^{\mathrm{b}}$ & 1.8 & $\dagger$ & NS & NS \\
\hline As long-term & $7.6^{\mathrm{a}, \mathrm{b}}$ & $7.2^{\mathrm{a}, \mathrm{b}}$ & $5.2^{\mathrm{b}}$ & $9.8^{\mathrm{a}}$ & 2.4 & $\dagger$ & NS & $\dagger$ \\
\hline Total & 16.7 & 16.4 & 15.6 & 17.0 & 1.0 & NS & NS & NS \\
\hline \multicolumn{9}{|c|}{ Adjusted energy balance ${ }^{4}\left(\mathrm{MJ} \cdot \mathrm{d}^{-1} \cdot \mathrm{kg}^{-0.60}\right)$} \\
\hline Total HP & 1.284 & 1.298 & 1.257 & 1.299 & 0.025 & NS & NS & NS \\
\hline Total RE & 1.040 & 1.026 & 1.067 & 1.025 & 0.025 & NS & NS & NS \\
\hline \multicolumn{9}{|l|}{ Energy utilisation } \\
\hline $\mathrm{NE}^{5} / \mathrm{ME}(\%)$ & 75.9 & 76.3 & 76.3 & 75.1 & 1.1 & NS & NS & NS \\
\hline $\mathrm{NE}^{5} / \mathrm{DE}(\%)$ & 73.5 & 73.6 & 73.7 & 72.1 & 1.0 & NS & NS & NS \\
\hline $\mathrm{NE} / \mathrm{NEg}^{5}$ & 100.6 & 100.9 & 102.2 & 100.2 & 1.5 & NS & NS & NS \\
\hline \multicolumn{9}{|c|}{ Energy values (MJ.kg-1 DM) } \\
\hline $\mathrm{DE}$ & $16.32^{\mathrm{a}}$ & $15.02^{\mathrm{b}}$ & $16.35^{\mathrm{a}}$ & $15.12^{\mathrm{b}}$ & 0.16 & $* *$ & NS & NS \\
\hline $\mathrm{ME}$ & $15.80^{\mathrm{a}}$ & $14.49^{\mathrm{b}}$ & $15.81^{\mathrm{a}}$ & $14.52^{\mathrm{b}}$ & 0.16 & $* *$ & NS & NS \\
\hline $\mathrm{NE}^{5}$ & $11.99^{\mathrm{a}}$ & $11.06^{\mathrm{b}}$ & $12.06^{\mathrm{a}}$ & $10.91^{\mathrm{b}}$ & 0.26 & $* *$ & NS & NS \\
\hline
\end{tabular}

$\mathrm{C}=$ control diet $\mathrm{MB}=$ maize bran diet $\mathrm{DM}=$ dry matter; $\mathrm{DE}=$ digestible energy; $\mathrm{ME}=$ metabolisable energy; $\mathrm{NE}=$ net energy; $\mathrm{FHP}=$ fasting $\mathrm{HP} ; \mathrm{HP}_{\text {act }}=$ activity $\mathrm{HP} ; \mathrm{TEF}=$ thermic effect of feed; $\mathrm{RSD}=$ residual standard deviation; NA = not applicable.

${ }^{1}$ From analysis of variance where main effects were animal within diet and litter $(n=10)$, litter $(n=5)$, diet $(n=2)$, growth stage $(n=2)$ and the interaction between diet and growth stage; the effects of animal and litter were not significant $(P>0.10)$. The interactions between stage and litter and between diet and litter were also tested but were not significant. Levels of significance: $\dagger, P<0.10$; *, $P<0.05$; **, $P<0.01$; NS, not significant. The same animals were used at growing and finishing stages and received the same diet.

${ }^{\text {a-c }}$ Mean values within a row with unlike superscript letters were significantly different, $P<0.05$.

${ }^{2}$ Mean body weight in the middle of the period in the respiration chamber.

${ }^{3}$ The additional peak of heat production (i.e. "ghost" phenomenon) was included in the short-term TEF (see text).

${ }^{4}$ Total HP and RE were adjusted for a ME intake of $2.324 \mathrm{MJ} \cdot \mathrm{d}^{-1} \cdot \mathrm{kg}^{-0.60}$ and for an activity heat production equal to $0.178 \mathrm{MJ} \cdot \mathrm{d}^{-1} \cdot \mathrm{kg}^{-0.60}$ (mean values for the experiment).

${ }_{5}^{5} \mathrm{NE}=\mathrm{RE}+\mathrm{FHP}$, where RE is adjusted for an activity heat production equal to $0.178 \mathrm{MJ} \cdot \mathrm{d}^{-1} \cdot \mathrm{kg}^{-0.60}$ (mean value for the experiment) and FHP corresponds to a zero activity FHP. NEg = average of NEg2, NEg4 and $\mathrm{NEg} 7$ values [16]. 
estimated daily and the values were averaged for each pig at each experimental period. The individual HP and RE data were adjusted for similar levels of physical activity and ME intakes (i.e., mean values of the experiment) according to the difference between actual $\mathrm{HP}_{\text {act }}$ and mean $\mathrm{HP}_{\text {act }}$, on the one hand, and the difference between actual $\mathrm{ME}$ and mean ME, on the other hand. The net energy (NE) value of the diet was calculated as the sum of FHP and RE where RE was adjusted for the mean level of physical activity [17]. All energy balance data were expressed as MJ per day and per kg of metabolic body weight $\left(\mathrm{MJ} \cdot \mathrm{d}^{-1} \cdot \mathrm{kg}^{-0.60}\right)$.

Experimental data were submitted to an analysis of variance with litter $(n=5)$, animal within diet and litter $(\mathrm{n}=10)$, diet $(n=2)$, growth stage $(n=2)$ and the interaction between diet and growth stage as the main effects. The effects of litter and animal within diet and litter were not significant $(P>0.05)$. The interactions between stage and litter and between diet and litter were also tested but were not significant. The GLM procedure of SAS was used for all statistical analyses [26]. The relation between $\mathrm{HP}_{\text {act }}$ while standing $\left(\mathrm{kJ} \cdot \mathrm{min}^{-1}\right)$ and $\mathrm{BW}$ was analysed using a non-linear regression method (NLIN procedure of SAS).

\section{RESULTS}

The chemical composition of the experimental diets is given in Table II and is in agreement with the aim of the experiment with regards to the DF level. All animals performed satisfactorily and average daily gain did not differ between the diets within each growth stage (Tab. III) but increased between growing (710 g) and finishing stages $(934 \mathrm{~g})$. According to the design of the experiment and as shown in Table IV, the pigs were fed the same ME level within each experimental period (2.4 and 2.3 $\mathrm{MJ} \cdot \mathrm{d}^{-1} \cdot(\mathrm{kg} \mathrm{BW})^{-0.60}$ for growing pigs and finishing pigs, respectively). As planned, feed intake increased over successive periods in relation with the variation in $\mathrm{BW}$ of the pigs during the experiment and differed between the diets (Tab. III).

\subsection{Digestive utilisation of dietary energy and nutrients}

The digestibility coefficients of nutrients, organic matter or energy were slightly greater in the heavier pigs, especially for the MB diet, but the difference was significant only for CP (Tab. III). The $\mathrm{N}$ intake was greater during the finishing period due to the greater feed allowance. Similarly, N excretion increased $(P<0.01)$ with the BW of the pigs. Accordingly, urinary energy losses were slightly greater $(P=0.08)$ in finishing pigs compared to growing pigs, so that the ME/DE ratio was lower for the former. The results presented in Table III also showed that the diet composition affected the digestibility of DM, organic matter, $\mathrm{CP}$, DF fraction (NDF and TDF) and energy, with the greater coefficients $(P<0.01)$ obtained for the $\mathrm{C}$ diet. The difference between the diets averaged 8 percentage points for digestibility coefficients of organic matter or energy, and was similar at both growth stages. The digestibility coefficient values of the ether extract should be interpreted with caution because of the low ether extract levels in the diets. Furthermore, faecal $\mathrm{N}$ losses were greater $(P<0.01)$ for the $\mathrm{MB}$ diet than for the $\mathrm{C}$ diet at each growth stage (Tab. III). On average for both growth stages, methane energy losses appeared numerically greater $(P=0.13)$ for the MB diet $(0.40 \%$ of DE) than for the $\mathrm{C}$ diet $(0.22 \%$ of DE); however they were highly variable $(\mathrm{RSD}=0.21 \%)$. Energy content of urine represented on average $3.2 \%$ of $\mathrm{DE}$ and was greater $(P<0.05)$ for the $\mathrm{MB}$ diet than for the $\mathrm{C}$ diet at each growth stage due to a greater daily $\mathrm{N}$ intake in the animals fed the MB diet. Consequently, the $\mathrm{ME} / \mathrm{DE}$ ratio was lower for the $\mathrm{MB}$ diet than for the $\mathrm{C} \operatorname{diet}(\mathrm{Tab}$. III). 
Table V. Behaviour and physical activity of growing and finishing pigs.

\begin{tabular}{|c|c|c|c|c|c|c|c|}
\hline \multirow{2}{*}{ Diet } & \multicolumn{2}{|c|}{ Growing pig } & \multicolumn{2}{|c|}{ Finishing pig } & \multirow{2}{*}{ RSD } & \multicolumn{2}{|c|}{$\begin{array}{c}\text { Significance } \\
\text { level }^{1}\end{array}$} \\
\hline & $\mathrm{C}$ & MB & $\mathrm{C}$ & MB & & Diet & $\begin{array}{l}\text { Growth } \\
\text { stage }\end{array}$ \\
\hline Body weight $(\mathrm{kg})^{2}$ & 42.1 & 43.6 & 77.9 & 78.5 & 1.1 & NS & $* *$ \\
\hline \multicolumn{8}{|l|}{ Behaviour $\left(\min \cdot \mathrm{d}^{-1}\right)$} \\
\hline Standing and eating & $55^{\mathrm{b}}$ & $56^{\mathrm{b}}$ & $68^{\mathrm{a}}$ & $67^{\mathrm{a}}$ & 2 & NS & $* *$ \\
\hline Standing and not eating & 159 & 131 & 132 & 123 & 42 & NS & NS \\
\hline Standing & 214 & 187 & 200 & 190 & 42 & NS & NS \\
\hline Lying & 1226 & 1252 & 1240 & 1249 & 42 & NS & NS \\
\hline Number of standing bouts $\left(\mathrm{d}^{-1}\right)$ & $41^{\mathrm{a}}$ & $32^{\mathrm{b}}$ & $31^{\mathrm{b}}$ & $24^{c}$ & 6 & $*$ & $*$ \\
\hline \multicolumn{8}{|l|}{$\mathrm{HP}_{\mathrm{act}}\left(\mathrm{kJ} \cdot \mathrm{d}^{-1}\right)$} \\
\hline Standing and eating & $263^{c}$ & $226^{\mathrm{c}}$ & $802^{\mathrm{a}}$ & $664^{b}$ & 40 & NS & $* *$ \\
\hline Standing and not eating & $554^{\mathrm{b}}$ & $585^{\mathrm{b}}$ & $918^{\mathrm{a}}$ & $977^{\mathrm{a}}$ & 191 & NS & $*$ \\
\hline Standing & $817^{\mathrm{b}}$ & $811^{\mathrm{b}}$ & $1720^{\mathrm{a}}$ & $1641^{\mathrm{a}}$ & 217 & NS & $* *$ \\
\hline While lying & $599^{b}$ & $570^{\mathrm{b}}$ & $1176^{\mathrm{a}}$ & $1146^{\mathrm{a}}$ & 155 & NS & $* *$ \\
\hline Total & $1416^{\mathrm{b}}$ & $1381^{\mathrm{b}}$ & $2896^{\mathrm{a}}$ & $2787^{\mathrm{a}}$ & 257 & NS & $* *$ \\
\hline \multicolumn{8}{|l|}{$\mathrm{HP}_{\mathrm{act}}\left(\mathrm{kJ} \cdot \mathrm{min}^{-1}\right)$} \\
\hline Standing and eating & $4.8^{\mathrm{c}}$ & $4.0^{\mathrm{c}}$ & $11.8^{\mathrm{a}}$ & $9.9^{\mathrm{b}}$ & 0.8 & $*$ & $* *$ \\
\hline Standing and not eating & $3.6^{\mathrm{b}}$ & $4.5^{\mathrm{b}}$ & $7.2^{\mathrm{a}}$ & $8.8^{\mathrm{a}}$ & 2.3 & NS & $*$ \\
\hline Standing & $3.9^{\mathrm{b}}$ & $4.4^{\mathrm{b}}$ & $8.7^{\mathrm{a}}$ & $8.9^{\mathrm{a}}$ & 1.0 & NS & $* *$ \\
\hline \multicolumn{8}{|l|}{$\mathrm{HP}_{\mathrm{act}}\left(\mathrm{kJ} \cdot \mathrm{min}^{-1} \cdot \mathrm{kg}^{-1}\right)$} \\
\hline Standing and eating & $0.114^{\mathrm{b}}$ & $0.093^{\mathrm{c}}$ & $0.151^{\mathrm{a}}$ & $0.127^{\mathrm{a}, \mathrm{b}}$ & 0.019 & NS & $*$ \\
\hline Standing and not eating & 0.086 & 0.102 & 0.092 & 0.112 & 0.035 & NS & NS \\
\hline Standing & 0.092 & 0.102 & 0.112 & 0.113 & 0.014 & NS & NS \\
\hline \multicolumn{8}{|l|}{$\mathrm{HP}_{\text {act }}\left(\mathrm{kJ} \cdot \mathrm{min}^{-1} \cdot \mathrm{kg}^{-1.25}\right)^{3}$} \\
\hline Standing and eating & 0.044 & 0.036 & 0.051 & 0.043 & 0.007 & NS & NS \\
\hline Standing and not eating & 0.034 & 0.040 & 0.031 & 0.038 & 0.013 & NS & NS \\
\hline Standing & 0.036 & 0.040 & 0.038 & 0.038 & 0.005 & NS & NS \\
\hline $\begin{array}{l}\text { Standing and eating HP } \\
\left(\mathrm{kJ} \cdot \mathrm{kg}^{-1} \mathrm{DM}\right)\end{array}$ & $163^{c}$ & $126^{\mathrm{c}}$ & $363^{\mathrm{a}}$ & $267^{\mathrm{b}}$ & 28.4 & $*$ & $* *$ \\
\hline $\mathrm{HP}_{\mathrm{act}}(\%$ of ME intake $)$ & $6.4^{\mathrm{b}}$ & $6.0^{\mathrm{b}}$ & $9.5^{\mathrm{a}}$ & $8.8^{\mathrm{a}}$ & 1.0 & NS & $* *$ \\
\hline
\end{tabular}

$\mathrm{C}=$ control diet; $\mathrm{MB}=$ maize bran diet; $\mathrm{DM}=$ dry matter; $\mathrm{ME}=$ metabolisable energy; $\mathrm{HP}_{\text {act }}=$ activity $\mathrm{HP}$.

${ }^{1}$ From analysis of variance where main effects were animal within diet and litter $(n=10)$, litter $(n=5)$, diet $(\mathrm{n}=2)$, growth stage $(\mathrm{n}=2)$; the effects of animal and litter were not significant $(P>0.05)$. The interactions between diet and growth stage, between stage and litter and between diet and litter were also tested but were not significant $(P>0.05)$. Levels of significance: *, $P<0.05$; **, $P<0.01$; NS, not significant. Each animal received the same diet at the growing and finishing stages.

a-c Mean values within a row with unlike superscript letters were significantly different, $P<0.05$.

${ }^{2}$ Mean body weight in the middle of the period in the respiration chamber.

${ }^{3}$ According to a non-linear regression model, $\mathrm{HP}_{\text {act }}$ while standing $\left(\mathrm{kJ} \cdot \mathrm{min}^{-1}\right)$ was proportional to the body weight raised to the power 1.25. Consequently, $\mathrm{HP}_{\text {act }}$ while standing was expressed as $\mathrm{kJ} \cdot \mathrm{min}^{-1} \cdot \mathrm{kg} \mathrm{BW}^{-1.25}$. 


\subsection{Metabolic utilisation of dietary energy}

The total HP represented on average $55 \%$ of $\mathrm{ME}$ and was greater $(P<0.05)$ in pigs fed the MB diet. However, this effect was due to differences in ME intake, and the differences were no longer significant when the HP values were adjusted to a similar ME intake (Tab. IV). FHP was the main component of total HP (56\%) and averaged (at zero physical activity) $0.724 \mathrm{MJ} \cdot \mathrm{d}^{-1} \cdot(\mathrm{kg}$ $\mathrm{BW})^{-0.60}$; the $\mathrm{HP}_{\text {act }}$ and TEF components represented on average 14 and $30 \%$ of HP (or 8 and $16 \%$ of $\mathrm{ME}$ ), respectively. The FHP, $\mathrm{HP}_{\mathrm{act}}$ and TEF components were quite similar between the diets at both growth stages. However, the TEF components were affected by the diet with a lower $(P=0.06)$ value of short-term TEF in the finishing pigs fed the $\mathrm{MB}$ diet. On the contrary, the long-term component of TEF was greater in finishing pigs fed the MB diet.

The results presented in Table IV also indicate that the growth stage affected the energy balance. In particular, $\mathrm{HP}_{\text {act }}$ was greater $(P<0.01)$ in finishing pigs $\left(0.207 \mathrm{MJ}^{-1} \mathrm{~d}^{-1} \cdot(\mathrm{kg} \mathrm{BW})^{-0.60}\right)$ than in growing pigs $\left(0.147 \mathrm{MJ} \cdot \mathrm{d}^{-1} \cdot(\mathrm{kg} \mathrm{BW})^{-0.60}\right)$. Pigs spent on average $86 \%$ of their time lying down. Nevertheless, a large proportion of energy cost of activity (about 60\%) was measured during standing (Tab. V). Despite the similar duration of standing at both stages $(P>0.05)$, the $\mathrm{HP}_{\text {act }}$ while standing (expressed as $\mathrm{kJ} \cdot \mathrm{d}^{-1}$ or $\mathrm{kJ} \cdot \mathrm{min}^{-1}$ ) was greater $(P<0.01)$ in finishing pigs than in growing pigs. The non-linear regression approach showed that the $\mathrm{HP}_{\mathrm{act}}$ while standing $\left(\mathrm{kJ} \cdot \mathrm{min}^{-1}\right)$ was proportional to the body weight raised to the power 1.25 . The exponent 1.25 differed significantly $(P<0.05)$

Table VI. Digestive and metabolic utilisation of maize bran in growing and finishing pigs ${ }^{1}$.

\begin{tabular}{|c|c|c|}
\hline Stage & Growing pig & Finishing pig \\
\hline \multicolumn{3}{|c|}{ Digestibility coefficients (\%) } \\
\hline Organic matter & 59.2 & 61.3 \\
\hline Crude protein & 66.4 & 67.9 \\
\hline Ether extract & 61.5 & 64.7 \\
\hline Crude fibre & 41.9 & 47.5 \\
\hline NDF & 41.5 & 48.3 \\
\hline $\mathrm{ADF}$ & 43.0 & 47.5 \\
\hline TDF & 39.1 & 44.8 \\
\hline Energy & 58.4 & 60.0 \\
\hline Energy as $\mathrm{CH}_{4}(\% \mathrm{DE})$ & 0.7 & 1.3 \\
\hline ME/DE (\%) & 94.5 & 93.0 \\
\hline NE/ME (\%) & 78.3 & 69.7 \\
\hline NE/DE (\%) & 74.0 & 64.8 \\
\hline \multicolumn{3}{|c|}{ Energy values $\left(\mathrm{MJ} \cdot \mathrm{kg}^{-1} \mathrm{DM}\right)$} \\
\hline DE & 11.44 & 11.75 \\
\hline ME & 10.81 & 10.92 \\
\hline NE & 8.46 & 7.61 \\
\hline
\end{tabular}

$\mathrm{DM}=$ dry matter; $\mathrm{NDF}=$ neutral detergent fibre; $\mathrm{ADF}=$ acid detergent fibre; $\mathrm{TDF}=$ total dietary fibre; $\mathrm{CH}_{4}=$ methane production; $\mathrm{DE}=$ digestible energy; $\mathrm{ME}=$ metabolisable energy; $\mathrm{NE}=$ net energy.

${ }^{1}$ Digestibility coefficients and energy values of maize bran were determined according to the difference method [20]. 
from $1,0.75$ or 0.60 . Moreover, the energy cost of activity during meal consumption (i.e. energy cost of eating) increased with the BW of the pigs. When expressed relative to the DM intake, it averaged 144 and $315 \mathrm{~kJ}$ per $\mathrm{kg}$ of feed in growing and finishing pigs, respectively. As a consequence, the total retained energy was lower $(P<0.05)$ in the finishing pigs $\left(0.981 \mathrm{MJ} \cdot \mathrm{d}^{-1} \cdot(\mathrm{kg} \mathrm{BW})^{-0.60}\right)$ than in growing pigs $\left(1.095 \mathrm{MJ} \cdot \mathrm{d}^{-1} \cdot(\mathrm{kg}\right.$ $\mathrm{BW})^{-0.60}$ (Tab. IV). The respiratory quotient decreased with $\mathrm{BW}$ in relation to a lower rate of lipid deposition in finishing pigs. Nevertheless, the effect of growth stage on total HP and retained energy was no longer significant when the energy balance data were adjusted for similar ME intake and $\mathrm{HP}_{\text {act }}$ values for the experiment (Tab. IV). Finally, the NE/ME ratio was neither influenced by the pig's BW nor by diet composition.

\subsection{Energy values of diets and maize bran}

Within each growth stage, energy values differed $(P<0.01)$ between the diets (Tab. IV). In fact, the energy value of the $\mathrm{C}$ diet was systematically greater than that of the MB diet. In addition, energy values of the diets were not affected $(P>0.05)$ by growth stage. The digestibility coefficients of organic matter, CP or energy of maize bran were slightly increased $(+2$ percentage points) with BW of pigs; the difference in digestibility between growth stages was most apparent for the DF fraction (+ 6 percentage points for NDF or TDF). Because of small variations of digestive utilisation of energy and nutrients with BW, the DE value of maize bran was only slightly higher for the growing than for the finishing stage $\left(+0.3 \mathrm{MJ} \cdot \mathrm{kg}^{-1} \mathrm{DM}\right)$. The ME/DE ratio was lower in finishing pigs due to greater $\mathrm{N}$ losses in urine (Tab. IV) and methane (Tab. VI) while the NE/ME ratio decreased in finishing pigs.

\section{DISCUSSION}

\subsection{Influence of body weight of pigs on digestive utilisation of energy}

As indicated in Table III, the increase in BW of pigs from 42 to $76 \mathrm{~kg}$ had little influence on the digestive utilisation of nutrients and the energy of the diets. The results obtained for the $\mathrm{C}$ diet are in agreement with previous studies which showed that the BW of growing animals has no effect on the energy digestibility coefficient for highly digestible diets [9, 21]. However, these studies also demonstrated that increased BW of pigs enhanced the energy digestibility coefficient of fibre-rich diets or fibrous ingredients in relation to greater digestibility of the DF fraction in heavier pigs. These observations were not confirmed in the present study (Tab. III), even though the digestibility coefficient of the DF fraction of maize bran increased numerically with BW (Tab. VI). The lack of an effect of BW on the digestive utilisation of MB could be partly due to the smaller range of $\mathrm{BW}$ of pigs used in this study $(34 \mathrm{~kg}$ ) compared to that of previous studies $(60 \mathrm{~kg})$. Nevertheless, according to Noblet and Shi [21], the increase in energy digestibility with similar diets would be equivalent to 1.0 percentage point between 42 and $76 \mathrm{~kg} \mathrm{BW}$ of pigs while the measured increase was a 0.6 percentage point (Tab. III). This smaller effect of BW can also be due to differences in the diet processing (mash feed in previous studies vs. pellets in the present experiment). Indeed, pelleting can improve the digestive utilisation of the diet but at variable extents according to the age of the animal [10]. Other processing techniques (grinding) have been shown to be more beneficial to small pigs than to heavier pigs [9]. Accordingly, it can be hypothesised that pelleting improved the digestibility of the diets in growing pigs more than in finishing pigs with a subsequent lower difference in digestibility coefficients between both stages in the present study. 


\subsection{Influence of body weight of pigs on the metabolic utilisation of energy}

It appears that the FHP or ME requirements for maintenance, expressed per kilogram $\mathrm{BW}^{0.60}$, were constant despite the increase in BW of the animals (Tab. IV). This confirmed the previous results obtained in our laboratory [22, 24, 29] which showed that an exponent close to 0.60 is satisfactory for predicting ME requirements for maintenance in growing pigs. In addition, van Milgen et al. [29] reported values of FHP ranging from 0.700 to $0.977 \mathrm{MJ}^{-1} \mathrm{~d}^{-1} \cdot(\mathrm{kg} \mathrm{BW})^{-0.60}$ from a literature survey. The mean value of FHP (for zero physical activity) obtained in the present study (Tab. IV) was situated in the lower part of this range and was close to the mean value estimated from a regression approach $\left(0.750 \mathrm{MJ}^{-1} \mathrm{~d}^{-1} \cdot(\mathrm{kg} \mathrm{BW})^{-0.60}\right)$ by Noblet et al. [17]. However, the FHP value measured in the present study was slightly lower than the mean value $\left(0.765 \mathrm{MJ} \cdot \mathrm{d}^{-1} \cdot(\mathrm{kg} \mathrm{BW})^{-0.60}\right)$ obtained by Noblet et al. [18] in a contemporary study with similar pigs and methodologies. However, in that latter study, the feed-

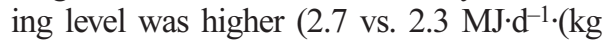
$\mathrm{BW})^{-0.60}$ ), and feeding level appears to affect FHP according to the conclusions of de Lange et al. (unpublished data) and Koong et al. [14].

The HP due to physical activity $\left(\mathrm{HP}_{\mathrm{act}}\right)$ represented approximately $8 \%$ of ME intake. This value was lower than those of the group-housed $25 \mathrm{~kg} \mathrm{BW}$ piglets $(11 \%$, [6]) or restrictively fed pregnant sows $(20 \%$, [25]) but similar to other results obtained for growing pigs under similar conditions [24]. The results of the present study also showed that $\mathrm{HP}_{\text {act }}$ differed according to the BW of pigs since it represented $6 \%$ and $9 \%$ of ME intake in growing and finishing pigs, respectively (Tab. IV). These results were similar to those of Quiniou et al. [24] measured at $25^{\circ} \mathrm{C}$ in 50 and $75 \mathrm{~kg} \mathrm{BW}$ grouphoused pigs. A large part $(60 \%)$ of total
$\mathrm{HP}_{\text {act }}$ was due to HP losses during standing (Tab. V). From a compilation of data obtained according to different measurement and calculation methods, Noblet et al. [16] suggested that the energy cost of the standing activity in pigs (i.e. piglets to adult sows) is much higher than in other species and is relatively constant per $\mathrm{kg} \mathrm{BW} \mathrm{BW}^{0.75}$. Our data did not confirm this suggestion in the specific case of growing pigs $\left(\mathrm{BW}^{1.25}\right)$, which is consistent with the observations of van Milgen et al. [30] suggesting 0.86 as the best exponent. These conflicting conclusions suggest that this aspect needs to be further investigated. In conclusion, physical activity varies considerably between pigs, especially with an increased BW, with subsequent differences in energy balance of pigs. It is therefore important to consider the level of activity of pigs in the determination of energy requirements of pigs or the NE value of the diets (Tab. IV).

The effect of BW on other HP components (e.g., TEF) and total HP was mainly due to differences in ME intake since there was no effect of BW on the energy balance when adjusted for a similar ME intake (Tab. IV). Finally, the NE/ME ratio of the diets was not affected by the growth stage of the pigs in agreement with the results of Noblet et al. [22]. The ratio between measured and calculated NE values (i.e. NE/NEg in Tab. IV) was close to $100 \%$ and was not affected by the stage of the pigs. In conclusion, our data confirmed the results of the NE system [22].

\subsection{Influence of dietary fibre on digestive utilisation of energy in pigs}

As expected from previous studies [5, 19], the introduction of a fibre-rich ingredient in the control diet reduced the digestibility of energy in growing and finishing pigs. From our results (Tab. III), it can be calculated that the digestibility coefficient of energy decreased by about 1 percentage 
point for each additional 1\% NDF in the diet. This result was similar to those obtained previously in 45 or $60 \mathrm{~kg} \mathrm{BW}$ pigs [20]. The lower digestive utilisation of the DF fraction (Tab. III) only partly explained these results, since approximately $50 \%$ of the DF fraction of the diet (Tab. III) or maize bran (Tab. VI) was digested in growing and finishing pigs. In fact, it appears that nutrient faecal losses (e.g., $\mathrm{N}$ or fat) increased in the presence of DF; this can be related to endogenous secretions associated with the higher microbial activity in the hindgut $[7,14,19]$.

In agreement with previous studies [17], total methane excretion represented an energy loss of about $0.3 \%$ of DE intake. In addition, the methane energy losses increased by $0.85 \mathrm{~kJ}$ for each additional gram of digestible NDF content in the diet (Tab. III). When using an enthalpy value of $18.1 \mathrm{~kJ}$ per gram of digestible NDF [15], it can be calculated that energy loss as methane represented about $5 \%$ (i.e. $0.85 / 18.1 \times 100)$ of the energy of digestible NDF. This value was close to the value proposed by Noblet and Le Goff [19] from a literature survey.

\subsection{Influence of dietary fibre on metabolic utilisation of energy in pigs}

In agreement with the observations of Ramonet et al. [13, 25] in adult gestating sows, FHP was not influenced by dietary DF content in the present study (Tab. IV). Similarly, the HP due to physical activity $\left(\mathrm{HP}_{\mathrm{act}}\right)$ was similar between diets at both growth stages (Tab. IV) despite a lower number of standing bouts and a decreased HP associated with standing and eating with the MB diet (Tab. V). This result did not confirm the data obtained in grouphoused growing pigs [27] or in adult sows [3], which indicate that animals are quieter with increased DF level. However, in agreement with the results of the present study, Ramonet et al. [13, 25] and Le Goff and
Noblet (unpublished data) found no effect of DF content on $\mathrm{HP}_{\text {act }}$ in adult sows housed individually in respiration chambers. In fact, $\mathrm{HP}_{\mathrm{act}}$ may be affected by numerous factors including feeding level, sources of $\mathrm{DF}$, feeding levels, housing conditions, body condition of animals, etc.

When adjusted for an average ME intake, total HP was not different between the diets (Tab. IV). This result contradicts with the NE prediction equations of Noblet et al. [17], which showed a greater heat increment for fibre-rich diets. Our results are also in contradiction with biochemical approaches which expected greater gas production $\left(\mathrm{CH}_{4}, \mathrm{H}_{2}\right)$ and fermentation $\mathrm{HP}$ and lower metabolic utilisation of fermentation products (i.e., volatile fatty acids) of animals fed fibre-rich diets [7]. For instance, it has been reported that a $1 \%$ increase in crude fibre of cereals depresses the NE utilisation by $0.7 \%$. The results of the present study also contradict with an increased HP relative to $\mathrm{ME}$ intake obtained in growing pigs [13] or gestating sows [25]. In this latter study, the difference of total HP between the diets was mainly due to differences in TEF, especially the long-term component of TEF $\left(\mathrm{TEF}_{\mathrm{lt}}\right)$. In the present study, even if $\mathrm{TEF}_{1 \mathrm{t}}$ increased in the finishing pigs fed the MB diet, this effect was counterbalanced by a lower $\mathrm{TEF}_{\text {st }}$ with, consequently, a similar total TEF between the diets (Tab. IV). However, the data obtained in growing pigs by Shrama et al. [27, 28] or Jørgensen et al. $[11,12]$ or in sows by Le Goff et al. (unpublished data) support our results since total HP was not affected by the DF level. It should be noted that the DF level of the diets differed between the studies. In fact, the effect of DF on total HP was mainly observed with particularly high fibre diets (300 to $400 \mathrm{~g} \cdot \mathrm{kg}^{-1} \mathrm{DM}$ ) [13, 25]. Accordingly, it can be hypothesised that the modification of total HP occurs only above a threshold level of DF in the diet. Alternatively, the presence of moderate levels of $\mathrm{DF}$ in the feed may reduce the metabolic 
activity of the gut or other body tissues. The lower energetic efficiency due to the heat of fermentation and the utilisation of its end products would then be compensated for.

\section{CONCLUSIONS}

In conclusion, our results confirmed that the introduction of a fibrous ingredient such as maize bran to a diet decreases the digestive utilisation of energy. However, in contrast to what could be expected from previous results, the effects were similar in growing and finishing pigs. Increased BW of pigs resulted in a greater HP due to physical activity with subsequent differences in energy balance between stages. When data were adjusted for a similar ME intake and HP due to activity, the total HP and its components were not affected by the DF level. These findings are supported by other results obtained under similar conditions but are in contrast with previous data obtained from mathematical or biochemical approaches.

\section{ACKNOWLEDGEMENTS}

The authors thank the GERNA (Paris) for financial support. The authors gratefully acknowledge R. Vilboux for preparing experimental diets, A. Roger and J. Delanoë for their technical assistance in animal care and $\mathrm{P}$. Bodinier and S. Hillion for laboratory analyses.

\section{REFERENCES}

[1] AOAC, Official Methods of Analysis (15th ed.), Association of Official Analytical Chemists, Washington, DC, 1990.

[2] BIPEA, Recueil des méthodes d'analyse des Communautés Européennes, Bureau Interprofessionnel d'Études Analytiques, Gennevilliers, France, 1976, pp. 105-111.

[3] Brouns F., Edwards S.A., English P.R., Influence of fibrous feed ingredients on voluntary intake of dry sows, Anim. Feed Sci. Technol. 54 (1995) 301-303.
[4] Brouwer E., Report of sub-committee on constants and factors, in: Blaxter K.L. (Ed.), Energy Metabolism of Farm Animals, Academic Press, London, 1965, pp. 441-443.

[5] Chabeauti E., Noblet J., Carré B., Digestion of plant cell walls from four different sources in growing pigs, Anim. Feed Sci. Technol. 32 (1991) 207-213.

[6] Collin A., van Milgen J., Dubois S., Noblet J., Effect of high temperature on feeding behaviour and heat production in group-housed young pigs, Brit. J. Nutr. 86 (2001) 63-70.

[7] Dierick N.A., Vervaeke I.J., Demeyer D.I., Decuypere J.A., Approach to the energetic importance of fibre digestion in pigs. 1. Importance of fermentation in the overall energy supply, Anim. Feed Sci. Technol. 23 (1989) 141-167.

[8] EEC, Analytical determination of starch, Official Journal of European Communities, Brussels, Belgium, 1972, p. 7 (L123).

[9] Fernandez J.A., Jørgensen J.N., Digestibility and absorption of nutrients as affected by fibre content in the diet of the pig. Quantitative aspects, Livest. Prod. Sci. 15 (1986) 53-71.

[10] Ginste J.V., Schrijver R.D., Expansion and pelleting of starter, grower and finisher diets for pigs: effects on nitrogen retention, ileal and total tract digestibility of protein, phosphorus and calcium and in vitro protein quality, Anim. Feed Sci. Technol. 72 (1998) 303-314.

[11] Jørgensen H., Energy utilization of diets with different sources of dietary fiber in growing pigs, in: McCracken K.J., Unsworth E.F., Wylie A.R.G. (Eds.), Energy Metabolism of Farm Animals, Proceedings of the 14th symposium on energy metabolism in animals, CAB International, Newcastle, Northern Ireland, 1997, pp. 367-369.

[12] Jørgensen H., Bach Knudsen K.E., Theil P.K., Effect of dietary fibre on energy metabolism of growing pigs and pregnant sows, in: Chwalibog A., Jakobsen K. (Eds.), Energy Metabolism of Farm Animals, Proceedings of the 14th symposium on energy metabolism in animals, CAB International, Snekkersten, Denmark, 2000, pp. 105-108.

[13] Jørgensen H., Zhao X.Q., Eggum B.O., The influence of dietary fibre and environmental temperature on the development of the gastrointestinal tract, digestibility, degree of fermentation in the hind-gut and energy metabolism in pigs, Brit. J. Nutr. 75 (1996) 365-378.

[14] Koong L.J., Ferrell C., Nienaber J.A., Assessment of interrelationships among level of intake and production, organ size and fasting heat production in growing animals, J. Nutr. 115 (1985) 1383-1390.

[15] Le Goff G., Noblet J., Comparative total tract digestibility of dietary energy and nutrients in growing pigs and adult sows, J. Anim. Sci. 79 (2001) 2418-2427. 
[16] Noblet J., Dourmad J.Y., Etienne M., Le Dividich J., Energy Metabolism in Pregnant Sows and Newborn Pigs, J. Anim. Sci. 75 (1997) 2708-2714.

[17] Noblet J., Fortune H., Shi X.S., Dubois S., Prediction of net energy value of feeds for growing pigs, J. Anim. Sci. 72 (1994) 344-354.

[18] Noblet J., Le Bellego L., van Milgen J., Dubois S., Effect of reduced dietary protein level and fat addition on heat production and nitrogen and energy balance in growing pigs, Anim. Res. 50 (2001) 227-238.

[19] Noblet J., Le Goff G., Effect of dietary fibre on the energy value of feeds for pigs, Anim. Feed. Sci. Technol. 90 (2001) 35-52.

[20] Noblet J., Perez J.M., Prediction of digestibility of nutrients and energy values of pig diets from chemical analysis, J. Anim. Sci. 71 (1993) 3389-3398.

[21] Noblet J., Shi X.S., Effect of body weight on digestive utilization of energy and nutrients of ingredients and diets in pigs, Livest. Prod. Sci. 37 (1994) 323-338.

[22] Noblet J., Shi X.S., Dubois S., Effect of body weight on net energy value of feeds for growing pigs, J. Anim. Sci. 72 (1994) 648-657.

[23] Prosky L., Asp N.-G., Schweizer T.F., DeVries J.W., Furda I., Determination of insoluble, soluble, and total dietary fiber in foods and food products: Interlaboratory study, J. AOAC 71 (1988) 1017-1023.

[24] Quiniou N., Noblet J., van Milgen J., Dubois S., Modelling heat production and energy balance in group-housed growing pigs exposed to low or high ambient temperatures, Brit. J. Nutr. 84 (2000) 97-106.

[25] Ramonet Y., van Milgen J., Dourmad J.Y., Meunier-Salaün M.C., Noblet J., The effect of dietary fibre on energy utilisation and partioning of heat production over pregnancy in sows, Brit. J. Nutr. 84 (2000) 85-94.

[26] SAS, SAS/STAT User's Guide (version 6 , 4th ed.), SAS Inst. Inc. Cary, NC, 1990.

[27] Schrama J.W., Bosch M.W., Verstegen M.W.A., Vorselaars A.H.P.M., Haaksma J., Heetkamp M.J.W., The energetic value of non starch polysaccharides in relation to physical activity in group-housed, growing pigs, J. Anim. Sci. 76 (1998) 3016-3023

[28] Schrama J.W., Verstegen M.W.A., Verboeket P.H.J., Schutte J.B., Haaksma J., Energy metabolism in relation to physical activity in growing pigs as affected by type of dietary carbohydrate, J. Anim. Sci. 74 (1996) 2220-2225.

[29] van Milgen J., Bernier J.F., Le Cozler Y., Dubois S., Noblet J., Major determinants of fasting heat production and energetic cost of activity in growing pigs of different body weight and breed/castration combination, Brit. J. Nutr. 79 (1998) 509-517.

[30] van Milgen J., Noblet J., Modelling energy expenditure in pigs, in: McNamara J.P., France J., Beever D.E. (Eds.), Modelling Nutrient Utilization in Farm Animals, CAB International, Wallingford, UK, 2000, pp. 103-114.

[31] van Milgen J., Noblet J., Dubois S., Bernier J.F., Dynamic aspects of oxygen consumption and carbon dioxide production in swine, Brit. J. Nutr 78 (1997) 397-410.

[32] Van Soest P.J., Wine R.H., Use of detergents in the analysis of fibrous feeds. IV. Determination of plant cell-wall constituents, J. AOAC 50 (1967) 50-55. 